Revised manuscript resubmitted to Ethnicities on 29 August 2016, after editorial decision (Minor revisions)

\title{
From Multiculturalism to Civic Integration: Citizenship Education and Integration Policies in the Netherlands and England since the 2000s
}

Co-authors: Paola Mattei and Miriam Broeks (RAND, Broeks)

\begin{abstract}
The paper discusses one of the most compelling policy issues facing liberal democracies in Europe: what policy tools can be used to promote social cohesion in a pluralist multi-ethnic society with different moral and religious and ethical values, and cultural and linguistic traditions? We focus on the role that citizenship education has taken since the early 2000s in light of the integration of immigrant children in schools in the Netherlands and England. Citizenship education is designed to integrate immigrant groups socially, foster their loyalty to the state, and encourage them to become engaged in democratic politics. Our empirical analysis advances our understanding of the policy ramifications of a new turn in integration policies directed towards stronger civic integration through sharing common values and moral standards.
\end{abstract}

Keywords: Multiculturalism; integration; immigrants; citizenship; radicalisation; schools 


\section{Introduction}

The Netherlands and England have been traditionally viewed as the standard-bearers of EU multiculturalism, particularly in relation to policies aimed at integrating immigrants and minority groups (Entzinger, 2006; Joppke, 2014; Rodriguez-Garcia, 2010). For instance, up until the mid-1990s Dutch schools taught ethnic minorities in their native language, establishing a separate state-funded school system for minorities, organising housing projects to accommodate their religious practices (Sniderman and Hagendoorn, 2007). Ethnic minorities policies in the Netherlands provided the arrangements for special treatment to specific target groups with a view to empower them and facilitate their emancipation. In England, until the late 1990s, diversity has been relegated to local communities and the private sphere, with Britishness largely unspoken due to its racial connotation. The state approach in England had traditionally been integrationist (Hill, 2013), until the clearly demarcated public-private divide was challenged by the 2001 riots in the North-East and then the 2005 terror attacks (Eade, Barrett, \& Flood, 2008). The British experience of integration was based on equal rights, anti-discrimination laws (Tomlinson, 2001b), and the 2005 terror attacks have been a catalyst for a negative view on immigration that shifted attention from ethnicity to religion (Leeman and Pels, 2006; Driessen and Merry, 2006).

It is widely argued that multiculturalist policies have been on the retreat (Race, 2015). In 2001, the Labour government in England declared that it was time to move "beyond multiculturalism" (Joppke, 2004). Immigrants should learn English 
and accept shared values. At the time, there was no populist extreme right party in England to which the slow retreat of multiculturalism could be attributed to. From the 2000s, in the Netherlands, the historical legacy of social cohesion paved the way to the individualisation of immigrants and the need to shift responsibility for social integration on them. In 1998, the Law on Civic Integration for Newcomers marked a new policy trajectory focused on learning the Dutch language and taking civic classes. Both countries converged at that point in time with a gradual retreat from multiculturalism as the celebration of diversity towards urging immigrants to adapt to the socio-cultural predominant matrix and values. In the Netherlands, the emergence of the extreme right Party for Freedom (Partij Voor Vrijheid), and its leader, Geert Wilders, and the murder of Dutch filmmaker Teo van Gogh by a fanatic Muslim have been a catalyst for negative public opinions views on immigrants (Sniderman and Hagendoorn, 2007).

In contrast to other studies (Sniderman and Hagendoorn, 2007; Hagendoorn and Sniderman, 2001), our paper analyses policies and what the English and Dutch governments did, rather than looking at party ideologies and discourses. This paper seeks to study the origins and development of civic integration as it emerged in the Netherlands and England since the early 2000s as an alternative and distinct integration approach from multiculturalism. This new approach rests on the centrality of shared civic values as a determinant component of integration in a multi-ethnic society. The civic integration agenda in these two European liberal democracies was aimed at creating a sense of identity and belonging among new immigrants and was originally marked by a process of distancing from the ethnicisation of social 
relationships that favoured special treatment to targeted groups. Most recently, policy reforms have created a new demand on immigrant groups to adhere actively and willingly to national 'values' or Western 'values'. In this paper, we analyse these recent changes in emphasis and evolution of the civic integration approach by empirically studying the instrument of citizenship education (CE). It was first introduced in England in 2002 for all pupils aged 11-16 in maintained schools. It was also adopted in the Netherlands in 2006.

The paper aims more specifically to explore the proposition that $\mathrm{CE}$, originally introduced in the early to mid-2000s both in the Netherlands and England to create social cohesion in multi-ethnic societies and facilitating the acculturation of minorities (Tomlinson, 2001a), has developed in recent years in an unexpectedly different direction as a result of the threat of radicalisation in schools and the rise of religious extremism. When CE was first introduced in the early 2000s, the main aims were social and moral responsibility, community involvement and political literacy (Keating, et al, 2010). CE prepares students to be responsible and active citizens in society, to learn about government institutions, and the political system. Students gain knowledge of the rule of law and justice and through CE develop an interest in local communities.

Against these aims, we suggest that the turn to civic integration in education policy has been increasingly dominated by the anti-radicalisation government agenda. The priorities of CE are less to encourage social cohesion and more to promote moral and spiritual values on groups that appear to be at risk of 
extremist ideas. This urgent demand to fighting against religious extremism has been translated into $\mathrm{CE}$ policies in schools that invoke national values. These values are similar to moral standards that provide a sense of political and social identity, coded in religious categories and religiously defined political identity (Taylor, 2007). The British government has introduced, for instance, Prevent legislation in 2015, that is part of the Counter-Terrorism and Security Act 2015 (Home Office, 2015a). Schools have an explicit requirement to promote fundamental British values which are defined as 'democracy, the rule of law, individual liberty, and mutual respect and tolerance of those with different faiths and beliefs' (Home Office, 2015:107). We suggest that policies and programmes of civic integration are slowly moving towards an integrationist model of integration that has resonance with the French Republican experience (Mattei and Aguilar, 2016) and is hostile to diversity. The French assimilationist model had been conceptualized as a mirror approach to the Netherlands and England (Hill, 2013). After presenting our conceptual framework, we will present out empirical findings for the two cases. A comparative discussion then explains commonalities and differences across-countries, with a focus on identifying new policy directions and approaches.

\section{Multiculturalism and changing integration approaches}

In our paper, we analyse the challenges to educational institutions in advanced liberal democracies in terms of combining liberal values and increasing cultural diversity. The English and Dutch integration policies have long been regarded as 'ideal types' of multiculturalism and often used as benchmark cases for policy 
learning in Europe (Brighton, 2007; Duyvendak and Scholten, 2012; Carol, Helbling and Michalowski, 2015). While these stereotypical models may have held true thirty years ago, there is currently a noticeable shift in the policy approaches of integration of immigrants (Gojulsing, 2006; Joppke, 2004; Joppke \& Morawska, 2014; Entzinger, 2006). Educational institutions are central to the socialisation of children and their social-cultural integration. CE programmes that vary across countries are vehicles to integrate an increasingly heterogeneous school population and promote social cohesion (Tomlinson, 2001; Modood, 2013). Before analysing the cases of England and the Netherlands, this section provides a conceptualisation of the relationship between the retreat of multiculturalism, the crisis of integration models and the new directions of CE (Bertossi, 2007). Multiculturalism is a loose concept, and no definition would be comprehensive enough. Kymlicka defines liberal multiculturalism as 'the view that states should not only uphold the familiar set of common civil, political and social rights of citizenship, but also adopt various group-specific rights or policies that are intended to recognize and accommodate the distinctive identities and aspirations of ethno-cultural groups' (Kymlicka, 2007:61)

In the context of an increasingly heterogeneous population in Europe, some scholars have distinguished between three different models of integration in a comparative European perspective (Aggestam and Hill, 2008). Although some scholars argue that models lie closer to political discourses (Bertossi, 2007), Aggestam and Hill provide a useful analytical framework that this paper adopts to compare the Netherlands and England. The assimilationist model resists the very notion of multiculturalism, opting for cultural homogenisation in the nation state 
(Anderson, 2006), as the French case illustrates best (Mattei and Aguilar, 2016). Minority groups and immigrants are expected to adopt the predominant national and cultural norms, language, and religion (Hill, 2013). France has retained an assimilationist approach. This is legitimated by implication of membership to a political and culturally homogenous community and nation-state. This is captured by the notion of the one and indivisible French Republic, which protects unity against any segmented identities (Doytcheva, 2011). The construction of a nationalized system of compulsory education promoting a centralized and standardized curriculum, focused on teaching the dominant groups' language and history is key.

The second type is multiculturalism. It grants rights to cultural and ethnic groups. Diversity is celebrated as a collective value and multicultural policies are designed by the political institutions to help immigrants integrate. The support of civic unity is compatible with diversity in public institutions and recognition of otherness. This model had been promoted in England and the Netherlands until recently as the paper argues. Germany and Austria have been associated for many years with a third model which is more exclusionary, whereby immigrants are merely guest workers who live and work temporarily in the host countries with the expectation of returning home (Aggestam and Hill, 2008; Kastoryano, 2005).

The scholarly debate on multiculturalism and its critics has centred on its ideological and discursive dimension (Reich, 2002). In a normative sense, multiculturalism is used as a value that supports cultural differences and calls for the equal recognition of different cultural identities. Multiculturalism's central claim is 
that the integration of immigrant minorities should process by means of 'recognising' the culture that constitutes a minority group. Multiculturalism is viewed as a rejection of earlier models of the unitary, homogenous nation-state (Kymlicka, 2007). As Miller argues, there has been an ideological retreat from multiculturalism insofar and politicians in different countries, and of different partisan affiliations, have been reluctant to endorse the goals of multiculturalism (Miller, 2006). This has been happening in Europe, more so, in the aftermath of the terror Paris November 2015 and Nice July 2016 attacks in France. In the Netherlands, politicians in favour of multiculturalism have lost support. As Bertossi argues, the 2005 terror attacks in London posed a serious challenge to the British integration model, that was not based on acculturation to the nation, but on equal access to equal rights (2007:4). In the public debate on national identity, for the first time, ethnic groups were criticized for their refusal to integrate culturally.

The failure of multiculturalism has been associated with the rise of socioeconomic marginalisation and segregation of ethnic groups, suffering from higher levels of unemployment, poverty and educational segregation (Mattei and Aguilar, 2016). Joppke (2004; Joppke \& Morawska, 2014) argues that multiculturalist policies have been replaced by a 'version of them' that resemble centrist policies of civic integration. Such citizenship policies are targeted to immigrants. Joppke argues that in the Netherlands there has been a retreat of multicultural policies because of the coexistence of recognition policies with emerging socio-economic problems (i.e. high unemployment, and high school dropouts). Entzinger points to the changeover of multicultural policies in the Netherlands to assimilation (2006). Some problems 
related to immigrants remained persistent throughout the $1990 \mathrm{~s}$, such as educational segregation and underachievement of immigrant groups, and high crime rates. In the Netherlands, he argues that there is now little room left for a public recognition of migrants' cultural identity. The state has retrenched funded programs intended at teaching in the native language of immigrants.

Why does the paper focus on CE and schools? Why not other public institutions? Schools are formidable institutional venues of civic integration, charged with the formation of citizens, enabling them to understand their rights and duties. Schools can integrate the second generation of immigrants by minimising the adverse impact of parental culture and removing language barriers. An existing problem in many European countries and diverse societies is that poverty and school dropouts are concentrated among ethnic minorities (Mattei, 2012). The education system plays a key role in generating social cohesion in pluralist societies (Gokulsing, 2006), such as England and the Netherlands. For instance, when looking at the evolution of educational integration policies and the teaching of citizenship in Dutch schools, changes in the focus of the purpose of integration are evident. It is during the late 1970s and early 1980s that the Dutch integration model was most strongly defined as multicultural. After realising that labour immigrants were to stay in the Netherlands, policymakers placed emphasis on their acculturation.

However, entering the 1990s a shift in emphasis in integration policies took place in the Netherlands and England. The focus on the socio-cultural integration of immigrants is replaced by an emphasis on their socio-economic integration into Dutch 
society (Leeman and Pels, 2006; Duyvendak and Scholten, 2012). The main focus became combating the socio-economic disadvantages of minorities, which was set to be achieved by reducing educational disparities through more effective modes of allocating funds to schools, rather than by providing Intercultural Education (Driessen, 2008). This was further accompanied by a shift in the emphasis in political discourse, in which individual responsibility (personal effort to fit within Dutch society) gained significance to achieve the successful integration of immigrants (Joppke, 2004; Joppke \& Morawska, 2014; Schuh, Burchardt, and Wohlrab-Sahr, 2012). This approach continued to be applied throughout the 2000s, emphasising the importance of active citizenship, stressing the rights and duties of immigrants. This is also reflected in wider integration policies outside of education. For example, new comers are required to take citizenship tests and learn the Dutch language to be granted a citizenship status in the Netherlands. We will also look at the Dutch Integration Agenda later in the paper, and measures to tackle radicalisation.

In the English case, between the early 2000s and 2010s, a clear-cut shift in its integration approach and CE is noticeable. In 2011 the counter-terrorism Prevent strategy introduces the notion of fundamental British values (FBV), and in 2015, statutory guidelines for schools to take part in Prevent and in promoting these values through CE were released (Prevent, 2011; Home Office, 2015a). These events mark a shift in the English integration approach towards one which resembles more closely a nationalistic one. PREVENT is hostile to diversity and multiculturalism. Alongside these developments, growing tensions between native and Muslim communities and Islamophobic sentiments have been rising in the past ten years (MCB, 2015). There is 
increased concern about the risk to alienate certain sections of society through the imposition of FBV in education. In our paper, the policy development of CE as an integration approach in relation to Prevent, is examined to explore whether a nationalistic and integrationinst approach is being established in England, at the expense of a multicultural citizenship approach (Race, 2015)

\section{Methodology}

The two cases in this paper were selected based on their institutional legacy of traditionally being ideal-types of multicultural models (Hill, 2013). Having this common denominator allows comparing any transformations and convergence or divergence thereof in the Dutch and English integration models. This choice was informed by the secondary literature (Carol, Helbling and Michalowski, 2015; Hill, 2013). Furthermore, these two European liberal democracies have similar economic contexts and demographic pressures affecting them (Eurostat, 2015). They face an increasingly heterogeneous immigrant population, with a largely predominant Muslim component that was the target of anti-radicalization measures.

This paper uses a comparative case study methodology suitable for the small-N sample. By using a case study analysis, a detailed picture of the key facets in the policy evolution of the countries' integration policies can be drawn (Thomas, 2015; Gomm, Hammersley and Foster, 2000). To do so legislations, governmental documents and reports, press releases from educational organisations and teacher associations, and news items were reviewed and encompass the data sources for the analysis. To identify this documentation a targeted search was carried focusing on 
items pertaining CE and radicalisation strategies at the school level for both countries. The time-span of the search encompasses the past fifteen years. Therefore, documents between 2001 and 2016 were sampled. When reviewing these materials a content analysis was undertaken aiming to pin point any approach changes and their direction (Krippendorff, 2012). The current analysis seeks to identify any changes in the direction of the integration approaches in both countries. As such, it does not seek to identify causality, but this is on the contrary an explorative study.

\section{From multicultural to integrationist citizenship: The case of England}

In this section, documentary evidence is presented to test the claim that a distinct approach from multiculturalism has emerged in England with regards to its integration policies for immigrants in schools (Race, 2015; Modood, 2013). The presented evidence seeks to demonstrate that the policy changes have been geared towards the promotion of FBV, national identity and 'Britishness'. To illustrate this, the introduction and policy development of CE in England is analysed. Alongside the policy evolution of $\mathrm{CE}$, data related to the English anti-radicalisation strategy is explored in brief. The focus is placed on 2011, when a clear policy change was introduced.

\section{Citizenship Education}

CE in England was first introduced in 2002. However, discussion about its introduction began in 1998. Concerns about the democratic and political participation of young people led to the commissioning of the Crick Report, to provide advice on 
how to give effective CE in schools (House of Commons, 2007). The Crick Report's findings suggested that $\mathrm{CE}$ should be made statutory. It was argued that $\mathrm{CE}$ was important for schools and 'the life of the nation' because it brings public benefits and contributes to the Social, Moral, Spiritual and Cultural (SMSC) development of pupils in accordance to what was required of schools by Clause 2 of the 1988 Education Reform Act (Education Reform Act 1988 c 40; Crick, 1998).

In September 2000 the first non-statutory guidance for CE was introduced in primary schools. In the summer of 2001, an environment of growing racial tensions developed into violent riots in three cities of Northern England (BBC News, 2001a). Increased segregation in neighbourhoods of these cities also rose concerns about religious hatred. Mr Bhailok from the Muslim Council of Britain (MCB) expressed that 'there is now a stronger case to outlaw religious discrimination and incitement to religious hatred' (BBC News, 2001b). These concerns about a lack of community cohesion led the Home Office to commission the 2001 Cantle Report to better understand the factors leading to these events and to try to better inform policies to improve societal cohesion. This report stated that:

'As a nation we have to assert a clearer set of expectations to govern attitudes to relationships between different sections of the community [...] This needs [...] an acceptance, and even a celebration, of our diversity and that within the concept of citizenship, different cultures can thrive, adding to the richness and experience of our nationality. That also means an acceptance that we are 
never going to turn the clock back to what was perceived to be a dominant or monoculturalist view of nationality.' ([own emphasis], Cantle, 2001:18)

This report recognizes the need to identify a common denominator to maintain community cohesion within a framework which has 'cultural pluralism' at its core (Parekh, 2000). By stating that 'we are never' going back to a 'dominant or monoculturalist view of nationality' this recommendation remains in line with an educative multiculturalist strategy. However, more recent policy shifts oppose this earlier statement and intention to embrace multiculturalism.

Under a climate of increased concern for the need to foment greater societal cohesion and democracy (Tomlinson, 2011a), the 2002 Education Act followed the Crick Report's recommendations and made it statutory for schools to teach CE. Since then, $\mathrm{CE}$ has to be provided by all maintained schools for pupils aged 11 to 16 . Section 78 of the 2002 Act specifies that schools are required to include and ensure that the SMSC development of students is promoted as part of the broad and balanced curriculum (DfE, 2014). According to the 2007 House of Commons Report on Citizenship Education, the motivations for this change in legislation were based on the belief that by introducing CE 'positive changes in young people's attitudes, behaviours and dispositions [would be achieved], leading for example to lower levels of disengagement and anti-social behaviour' and increased democratic participation (House of Commons, 2007: 6). The Ajegbo Report similarly provided recommendations to improve the CE curriculum to nurture pupils' 'skills to participate in an active and inclusive democracy', while 'appreciating and 
understanding difference' (DfES, 2007:3). Therefore, these document evidence that at this point in time emphasis was placed on attempting to socially and politically engage those members of society, particularly the young, who experienced alienation, rather than on promoting one British culture.

Furthermore, in accordance to the statutory requirement of schools to provide CE, the role of Ofsted was further extended to inspect schools' compliance with the promotion of pupils' SMSC development (Education Act 2005, c 18; Ofsted, 2015). Despite this provision, the approach to CE was criticized for remaining as a 'light touch' one which enabled schools much freedom in terms of delivery (DfES, 2007; House of Commons, 2007; Keating et al., 2010). This in combination with concerns of increased societal tensions resulted in the Education and Inspections Act 2006 (c 40), which incorporated a new Section 12(5) to the 2002 Education Act. This incorporation legally required governing bodies of maintained schools to play a role in the promotion of community cohesion. Emphasis was also placed on dealing with identity and diversity (House of Commons, 2007). This evidence shows that up until this point it is clear that the English government and CE focused on the issue of community cohesion, and on increasing political participation of young people. However, from 2011 onwards, and increasingly so since 2014, it is clear that the focus falls more strongly on countering terrorism and promoting a sense of nationalistic Britishness.

Prevent strategy and anti-radicalisation 
Alongside these developments, concerns about terrorism and extremism also arose. As a response to the 2001 9/11 terrorist attacks, the Home Office's CONTEST counter-terrorism strategy was established in 2003 (Parliament Communications, 2009). With the 2005 London bombings bringing the terrorist threat home, national protection strategies increased. This resulted in various public institutions, including schools, being required to aid identify and prevent people from being drawn into terrorism (Home Office, 2015a).

In 2007, the Prevent strategy was established and became part of CONETST in 2009. In 2011, Prevent established a set of FBV, described as 'democracy, the rule of law, individual liberty, and mutual respect and tolerance of those with different faiths and beliefs' (Home Office, 2011:107). Between 2011 and 2014 a significant change took place. At its initial stages, in 2011, Prevent only required public bodies, and henceforth schools, to recognize or 'not to undermine' these FBV, in other words, they ought to respect them.

However, in November 2014 the Department for Education released a report providing non-statutory guidance on 'Promoting FBV as part of SMSC in schools' (DfE, 2014). A clear shift in the English approach is identifiable. From requiring schools to 'respect' FBV, now they have to 'actively promote' them. According to this report, actively promoting these values means 'challenging opinions or behaviours in school that are contrary to [FBV]. Attempts to promote systems that undermine [them] would be completely at odds with schools' duty to provide SMSC' (DfE, 2014:5). Therefore, schools ought to ensure that pupils understand that people 
living in England are subject to its law, despite the fact that 'different people may hold different views about what is 'right' and 'wrong' (DfE, 2014:4). Schools cannot teach anything which undermines 'supporting the rule of English civil and criminal law'. Furthermore, 'extremism' is defined as the 'vocal or active opposition to fundamental British values, including democracy, the rule of law, individual liberty and mutual respect and tolerance of different faiths and beliefs' (Home Office, 2015b:2). While the guidance provided by the Department for Education is nonstatutory, schools have the statutory duty to take part in Prevent. Given how Prevent is interwoven with the SMSC development of students that educational institutions have to ensure, it is difficult for maintained schools not to comply with the guidance to promote FBV. As stated by a spokesperson of the Department for Education, requiring schools to teach FVB is necessary to ensure that children are being prepared for life in modern Britain (UK Government Press Release, July 2014).

There has been much debate regarding the English governmental definitions of FVB and extremism. Many consider them extremely limited (Easton, 2014; Cairns, 2105; Qurashi, 2016; Adams, 2016). In regards to extremism, there is concern about its focus being too narrowly directed to 'safeguarding risks posed by religious extremism', while, as the Association of Teachers and Lecturers (ATL) points, it should better encompass other forms of extremism (ATL, 2014:2). They are concerned about the impact this is having on the way Muslims are viewed within education. Therefore, ATL calls the government to consider other factors that encourage the radicalisation of young people, such as their disadvantaged socioeconomic prospects, and to reconsider the increasing pressure put on teachers: 
educators can have a role in preventing radicalisation but should not be made the 'main protagonists in the battle for young hearts and minds' (ATL, 2014:3). Similarly, the Muslim Council of Britain criticizes the Prevent strategy, and sees it as potentially counter-productive and as likely increasing the risk of alienation of Muslim communities (MCB, 2015). By 2016, the English integration approach resembles more closely an assimilationist model since, as defined by Hill (2013), minority groups are expected to adopt predominant national norms.

\section{The resilience of integrationist approaches: the Dutch case}

Similar to the English case, changes in Dutch integration policies show a shift away from the traditional multicultural approach. In 2004, for instance, public funding for teaching immigrant's native languages in primary and secondary schools was withdrawn (EK, Bill nr.29019, 2004). Since 2006, all Dutch schools have the statutory duty to play a part in the citizenship formation and integration of pupils (TK, 2005). With this legislative change greater emphasis was placed on 'common basic values' (basiswaarden) to increase social cohesion (OCW and Education Inspectorate, 2006). Furthermore, since 2014, strategies to tackle radicalisation and extremism have, like in England, permeated the education sphere.

While a shift in emphasis within Dutch integration policies has undeniably taken place, this paper argues that the extent to which this has occurred remains closer to multiculturalism than to an assimilationist model. While the concept of 'basic values' has emerged in the political discourse, these values are interchangeably referred to in policy documents and governmental reports as democratic, European or 
Western (OCW and Education Inspectorate, 2006; SLO, 2015). There are no 'one' nationally defined set of 'Dutch values', broad governmental guidance is given to aid their definition, and individual schools determine them and decide which values to emphasize in accordance to their student population and context (SLO, 2015). The documentary analysis identifies elements within these policies which resist the homogenisation of a national Dutch identity.

\section{Citizenship Education}

A shift in policy approach is identified from 2004 onwards, when 'common citizenship' rather than 'active citizenship' becomes emphasized (Duyvendak and Scholten, 2012). The importance of equipping immigrants with the necessary knowledge and skills to be part of society is highlighted. Mastering Dutch and acquiring knowledge of Dutch values, norms and of the most important social institutions of the Netherlands were considered key elements to achieve this (TK, 2003-2004, 29 203, nr. 1).

In the educational sphere, the Ministry of Education released a policy note on 'Education, Integration and Citizenship' (OCW, 2004). This document acknowledges the need to revise the role of schools, communities and national government to combat educational disadvantages, and to adapt to the changing ethnic, cultural and religious composition of the now highly plural Dutch society. The report pointed to the problem of the slow integration of minorities and the low educational achievement of some Islamic schools and schools with high immigrant pupil 
populations. It is finally stated that $\mathrm{CE}$ will receive a legal basis. However, it is worth highlighting that none of these documents focus or emphasize 'Dutch values'.

In December 2005 a 'citizenship mission' (burgerschapsopdracht) for schools was introduced into Dutch education law and became effective in 2006 (TK, 2005). Article I, Section 8 of the Education Law for primary education was changed to state that education: 'a) takes into consideration that students grow up in a plural society (Parekh, 2000); b) aims to promote active citizenship and integration; And c) aims to make students acquainted with and gain knowledge of the different backgrounds and cultures of their peers' ([translation] TK, 2005:6). A ninth paragraph was also added, stating that education should be structured such as to pay attention to inequalities and to combat them, particularly in the area of mastering the Dutch language. These changes were further applied to Article III for secondary education. These legislative changes once again show a move away from multiculturalism by, for example, requiring the mastery of Dutch language. However, this is present alongside the requirement to teach students about the different backgrounds and cultures of their peers and acknowledges the increasingly diverse composition of Dutch society.

Furthermore, and in contrast to England, the government recognizes that defining 'Dutch values' is a complex task. Instead, it specifies six essential values that make a democratic state:

'Equality leading to equal treatment/non-discrimination; Freedom of religion and belief; Freedom of speech; Freedom of association, assembly and demonstration; 
Respect for privacy; Inviolability/integrity of the human body.' ([translation], SLO, 2006a: 23)

Additionally, the Education Inspectorate evaluates schools' compliance to their citizenship mission by overseeing that they pursue the Core Objectives within Section 7 titled 'Basic values and the democratic state' for primary (objectives nr.36, 37 and 38) and secondary education (objectives $\mathrm{nr} .43,44$ and 45). It is worth highlighting that these Core Objectives refer to teaching pupils both Dutch and European politics, democracy and citizenship, and when mentioning values, these are set as 'generally accepted norms'. Furthermore, in regards to religious diversity, students need to learn about the multicultural society they live in and to 'learn to respect the differing views of people' ([translation], OCW and Education Inspectorate, 2006:13). This evidences that policy emphasis is placed on learning to live in diversity based on respecting difference, rather than on attempts to hegemonize 'Dutchness'.

In regards to Dutch CE, no policy changes took place between 2006 and 2012. This was a period of implementation at the school level. The National Institute for Curriculum Development (SLO) was in charge of overseeing and providing advice for effective implementation as commissioned by the government (SLO, 2006a; 2006b; 2008; 2009). In its 2012 evaluation report, SLO identified that there was little cohesion in the approaches pursued by schools to implement CE (SLO, 2012), and recommends the government, among other aspects, to formulate more clearly the core objectives and values of CE.

\section{Integration agenda}


SLO's (2012) recommendation to more clearly state the core objectives and values of CE provided an opportunity window to move towards a Dutch-centred approach. However, this is not observed in the Dutch case as is in England. While as part of the 2013 Year Briefing, the State Secretary of Education, S. Dekker, states that citizenship is about the values 'we' share, and about having knowledge about 'our' political institutions, it is also about appropriate behaviour and the rules which apply in a diverse society (OCW, 2013). In accordance to this claim, the Integration Agenda specifies that CE should not impose ideas on children but teach them how to reflect on democracy, their own ideals and that of others to help form their identity (Integration Agenda Appendix, 2014), By emphasising these aspects, it seeks to increase pupil's understanding of diversity to achieve greater respect between different groups in Dutch society.

These objectives gained importance with the growing societal tensions reported in 2013 and 2014. These encompassed increased crime and violent acts by Moroccan youths, and the rise in the political presence and support of the antiimmigrant populist right-wing politician Geert Wilders (Kern, 2014). In 2014, two demonstrations, one anti-ISIS and the other pro-ISIS, took place in The Hague (RTL, 2014a). Furthermore, by November 2014, it was reported that approximately 160 Dutch jihadists left to Syria or Iraq (RTL, 2014b). These events and facts reveal that religious tensions and danger of radicalisation are also highly present in the Netherlands, and reinforce the importance given to the role of CE by the Dutch government. 
Regarding radicalisation and extremism the Ministry of the Interior and Kingdom Relations released a report about 'The various threats from radical Islam to the democratic legal order' (BZK, 2004). The report provided governmental definitions for extremism and radicalisation. It stated that in the context of education, radicalisation problems are widespread and two possible directions can be taken: 'First, schools might play a role in the identification of radicalisation and informing the competent authorities. Second, they can transfer and encourage the internalisation of the Western democratic ideas on legal order.' (BZK, 2004:51). This statement hinted to the role schools were to acquire in 2006 in terms of CE and from 2014 onwards in regards to tackling radicalisation. Most importantly, the report discussed the transmission of 'Western democratic ideas' or values, rather than 'Dutch' ones, which contrasts with the English definitions. This provides further evidence for a differentiation between the two countries regarding their policy changes. Similarly, the definitions of extremism and radicalisation established in the report, are broader than the English ones since they do not refer to Dutch values at any point (SWZ, 2004; BZK, 2016). Finally, these 2004 definitions are still currently used (BZK, 2016).

Furthermore, in 2014, the government released a report summarizing the measures and actions of the 'Integrated approach towards Jihadism' (VJ, NCTV and SZW, 2014). This document sets guidelines for schools on how to tackle Jihadist threats and establishes that the government will provide greater support to educational institutions to carry their task to spot pupils at risk of radicalisation (OV-Raad, 2015). In 2015, these regulations were strengthened (SLO, 2015), and the law on 'School 
Safety' was adapted to include the duty of schools to protect the 'social, psychological and physical safety of students' (Staatsblad 238, [primary] art.1-4c, [secondary] art.33b, 2015:1). The latter made it statutory for schools to aid in tackling radicalisation. Nonetheless, the Ministry of Education clearly stated that no one approach would be established by central government (OCW, 2015). This shows the importance given by the Dutch approach to context specific solutions rather than the homogenisation of 'Dutchness'.

To conclude, while there is evidence that the Netherlands has moved away from multiculturalism, reviewing any transformations in the area of CE, it is difficult to claim that the changes have meant a turn towards an assimilationist strategy to the same degree as in England.

\section{Comparative Discussion}

\section{Citizenship Education}

The Dutch integration approach began focusing on shared values to achieve greater social cohesion since 2004. Still, when the 'citizenship mission' of schools to teach CE is legally instituted in 2006, the 'democratic values' which characterize Dutch society are not defined. The government provided examples of shared values: these encompass a broad set of areas (democracy, equality, human integrity and environmental responsibility) and are intended as broad guidance for schools. The governmental importance given to the autonomy of schools to define their teaching curriculum is protected up until the present, as demonstrated by SLO's guidance 
report about 'finding shared values' released in November 2015 (SLO, 2015). This document resulted from the compromise made by the Ministry of Education to provide greater support to schools in defining their CE content earlier that year. The importance of taking into account the context of each school and therefore including the opinion of parents and pupils when defining school values and, hence, the values which are to be taught in $\mathrm{CE}$ classes, is the most prominent guidance provided in this document. As a result, there are no nationally defined set of values within CE, and it is left to the discretion of schools to define values they consider are relevant to their context and Dutch, European and or Western society.

This paper shows that the English trajectory of CE is markedly different and observes a shift towards promoting national values. It is from 2011 onwards that assimilationist traits are identified most strongly. Previously, the main concern of CE was to increase democratic participation and multiculturalism was celebrated in England, as shown by both the Crick (1998) and the Cantle (2002) reports. However, schools were put under pressure to promote FBV throughout their curriculum and particularly through CE when 1) FVB were established under Prevent in 2011, 2) when the promotion of FBV and the safeguarding of the SMSC development of pupils were linked within CE in 2014, and 3) with the introduction of the 2015 Counterterrorism and Security Act which mandates public institutions to participate in preventing radicalisation. This differs from the Dutch case, and reveals an approach which focuses on promoting a uniform set of values concerning national identity.

\section{Preventing radicalisation in schools}


In both countries their counter-terrorism strategies have been adapted in the past five years to incorporate schools. Two elements of these strategies are worth discussing. First, the definitions given to radicalisation and extremism, and second, the way schools ought to comply with their Prevent duty.

Regarding the definitions given to radicalisation and extremism, these differ in both countries. The analysis showed that these terms were defined in 2004 in the Netherlands in a broad manner to include various types of extremism and to refer to acts which mainly defy the democratic order. Furthermore, these 2004 definitions continue to be used in 2016. In contrast, in England, these terms were defined in relation to FBV in 2014. Hence extremism is said to be the active or vocal opposition to British values, and schools' duty to promote them means challenging any opinions which go against them.

A further difference between the two countries pertains how schools have to comply with their duty to prevent extremism or radicalisation. In 2014 in the Netherlands, the 'Integrated approach towards Jihadism' was released establishing that educational institutions would play a part in tackling an extremist threat. In 2015, the Ministry of Education provided further information about this new mandate but clarified that there would be no 'single' approach centrally established by government (OCW, 2015). Instead, each school will be provided, among other types of support, access to an information hub where to consult their specific cases to identify the best solution. Furthermore, within documents about approaching radicalisation, values are not mentioned. Instead one of the objectives of the document is to protect democracy 
and the legal state (VJ, NTCV and SZW, 2014). In contrast, in England, the Ministry of Education released non-statutory guidance on how schools should promote FBV, and in 2015 the Home Office released the revised statutory Prevent duty guidance which has national reach (Home Office, 2015b). It determines that schools should demonstrate activity in accordance with the 2015 Counter-Terrorism and Security Act.

Discussing the evidence in terms of counter-terrorism strategies in schools shows a similar trend as identified for CE. For England, the Prevent strategy is strongly framed in relation to FBV which consequently goes in line with a nationalistic turn. In the Netherlands, the requirement of schools to tackle radicalisation is not linked to values.

\section{Conclusion}

By examining integration policies of immigrants at the school level in England and the Netherlands, this paper sought to establish whether their integration models are moving away from multiculturalism and instead converging towards an assimilationist stance based on security, which views diversity as a challenge to shared liberal values and national identity. The analysis of the Dutch and English cases reveals that, while both countries underwent similar political and socioeconomic pressures to restructure their integration policies in the past fifteen years, policy changes reflect slightly divergent approaches. The English experience is becoming more Republican (Mattei and Aguilar, 2016), whilst the Dutch integration policies are firmly entrenched in the integrationist framework whereby individuals are 
given rights through the promotion of equal opportunities and equal access to state institutions and programmes.

The analysis focused on two elements of integration policies at the school level: first, $\mathrm{CE}$ and the new direction towards moral achievements, and, second, on the regulations to tackle radicalisation. In the case of England, it is evident that at the school level, its multicultural tradition has been slowly reverted for an implementation of policies that are highly tainted of integrationist traits (Race, 2015; Modood, 2013). In the case of the Netherlands, the reforms have resulted in an integration approach that is still committed to its history of multicultural education. When superficially compared along political discourses, England and the Netherlands seem similar in that in both cases there is a growing emphasis towards a uniform national identity. There is in both countries emphasis on common values and a trend towards paternalistic control. Citizenship is to be earned through moral achievements.

However, after evaluating substantive policies it becomes clearer that in England CE accentuates the urge to assimilate non-Western students, whereas in the Netherlands the moral obligations are much less pronounced. Building upon the findings, this paper contributes to the literature mainly in two ways. On the one hand, it presents a different argument to the literature which argues that the Netherlands has unequivocally moved away from multiculturalism (Duyvendak and Scholten, 2012; Schuh, Burchardt and Wohlrab-Sahr, 2012), while on the other, it supports literature which suggests that English policies have become less multicultural and more integrationist (Modood and May, 2001; Race, 2015; Modood, 2013). We argue that in 
England a turn towards integrationit policies in schools has taken place. In the Dutch case, the main aim of $\mathrm{CE}$ is not tackling radicalisation, but remains the promotion of democratic participation and social cohesion.

\section{References}

Aggestam L, and Hill C (2008) The challenge of multiculturalism in European foreign policy. International Affairs, 84(1), 97-114.

Adams R (2016) Teachers back motion calling for Prevent strategy to be scrapped Available at: http://www.theguardian.com/politics/2016/mar/28/teachers-nutback-motion-calling-prevent-strategy-radicalisation-scrapped (accessed 01 June 2016).

ATL (August, 2014) Proposed new independent school standards, parts 1, 2 and 4:

Response from the Association of Teachers and Lecturers. Available at: https://www.atl.org.uk/Images/2014_Independent_Sector_Standards_parts 1 12 4.pdf (accessed 5 December 2015).

BBC News (2001a, July 12) Summer of discontent. Available at: http://news.bbc.co.uk/2/hi/uk_news/1435958.stm (accessed 22 May 2016).

BBC News (2001b, July 16) Muslims call for riots enquiry. Available at: http://news.bbc.co.uk/2/hi/uk_news/1440772.stm (accessed 22 May 2016). 
BZK (2004) From dawa to jihad: The various threats from radical Islam to the democratic legal order. Ministry of Interior and Kingdom Relations. The Hague: General Intelligence and Security Service, pp.1-58.

BZK (2016) De termen activisme, extremisme en terrorisme worden soms door elkaar gebruikt. Toch zijn er wel degelijk verschillen. [The terms activism, extremism and terrorism are sometimes used interchangeably: but they are different] Available at: https://www.aivd.nl/onderwerpen/extremisme (accessed 22 May 2016).

Carol S, Helbling M and Michalowski I, (2015) A Struggle over Religious Rights? How Muslim Immigrants and Christian Natives View the Accommodation of Religion in Six European Countries. Social Forces, 94(2), pp.647-671.

Cantle T (2001) Community cohesion: A report of the independent review team. Home Office, 1-80.

Cairns R (2015) "Gove was right to insist on British values in schools" Available at: http://www.telegraph.co.uk/education/educationopinion/11335598/Gove-wasright-to-insist-on-British-values-in-schools.html (accessed 10 December 2015).

CBS (2014) Migration of the four largest cities in the Netherlands. Statistics Netherlands. Available at: https://www.cbs.nl/NR/rdonlyres/24BAD693-1CB94D14-9BC8-FA94A87F6727/0/migration.pdf (accessed 22 May 2016).

Crick B (1998) Education for citizenship and the teaching of democracy in schools. Final report, 22 September 1998. 
DfE (November, 2014) Promoting fundamental British values as part of SMSC in schools. Reference DFE-00679-2014, pp.1-9.

DfE (July 2015) Keeping children safe in education: Statutory guidance for schools and colleges. Reference: DFE-00129-2015, pp.1-61.

DfES (2007) Diversity and citizenship - curriculum review - the Ajegbo Report. Reference: 00045-2007DOM-EN, pp.1-126.

Doytcheva M, (2011) Le multiculturalisme. La Découverte.

Driessen G and Merry MS (2006) Islamic schools in the Netherlands: Expansion or marginalization?. Interchange, 37(3), pp.201-223.

Driessen G (2008) Towards Citizenship Education in the Netherlands. Country Report. Torino, It: International and European Forum on Migration Research.

Duyvendak JW and Scholten P (2012) Deconstructing the Dutch multicultural model:

A frame perspective on Dutch immigrant integration policymaking. Comparative European Politics, 10(3), 266-282.

Eade, J., Barrett, M., \& Flood, C. (Eds.). (2008). Advancing multiculturalism, post 7/7. Newcastle: Cambridge Scholars Publishing.

EK (2004) First Chamber bill nr.29019, Netherlands.

Easton M (2014) Should teachers 'promote' British values? Available at: http://www.bbc.co.uk/news/uk-27784747 (accessed 16 November 2015) 
Education Act 2005, c 18 England. Available at:

http://www.legislation.gov.uk/ukpga/2005/18/contents (accessed 27 August 2016)

Education and Inspections Act 2006, c 40, England.

http://www.legislation.gov.uk/ukpga/2006/40/contents (accessed 27 August 2016)

Education Reform Act 1988, c 40, England. Available at:

http://www.legislation.gov.uk/ukpga/1988/40/contents (accessed 27 August 2016)

Education Inspectorate (2006) Toezicht op Burgerschap en Integratie. [Supervision of Citizenship and Integration]. Utrecht: GSE, ISBN-10:90-8503-060-9.

Entzinger H (2006) The parallel decline of multiculturalism and the welfare state in the Netherlands. In Banting K. and Kymlicka W. (eds.), Multiculturalism and the Welfare State, Oxford University Press, pp.177-201.

Eurostat (2015) Migration and migrant population statistics. Available at: http://ec.europa.eu/eurostat/statisticsexplained/index.php/Migration_and_migrant_population_statistics (accessed 26 May 2016)

Gomm R, Hammersley M and Foster P (2000) Case study method: Key issues, key texts. London: Sage.

Gutmann A (1995) Civic Education and Social Diversity. Ethics, 105(3), 557-579. 
Hagendoorn, L. and P. Sniderman (2001) Experimenting with a National Sample: a Dutch Survey of Prejudice. Patterns of Prejudice. 35, pp. 19-31.

Hill, C (2013) The National Interest in Question. Foreign Policy in Multicultural Societies. Oxford: Oxford University Press.

Home Office (2011) Prevent Strategy. ISBN: 978-0-10-180922-1, pp.1-116.

Home Office (2015a) Counter-Terrorism and Security Act. ISBN: 978-0-10540615-0, pp.1-80.

Home Office (2015b) Revised Prevent Duty Guidance: For England and Wales. ISBN: 978-1-78246-7933-9, pp.1-14.

House of Commons (2007) Citizenship Education: Second Report of Session 200607. London: The Stationery Office Limited, pp.1-357.

Integration Agenda Appendix (2014) Overzicht Voortgang Agenda Integratie per november 2014: Bijlage bij brief Voortgang Agenda Integratie. [Overview of the Integration Agenda's progress by November 2014: Annex of Integration Agenda progress letter]. pp.1-13, Available at: https://www.rijksoverheid.nl/documenten/rapporten/2014/11/21/overzichtvoortgang-agenda-integratie-2014 (accessed 24 May 2016)

Integration Agenda (2013) Integratiebeleid 32824 nr. 7 [Integration policy], Netherlands. 
Integration Agenda (2014) Kamerbrief 'Voortgang Agenda Integratie 2014'.

[Legislative letter 'Integration Agenda progress 2014]. Report no: 20140000175902, Netherlands.

Joppke C (2004) The retreat of multiculturalism in the liberal state: theory and policy. The British journal of sociology, 55(2), 237-257

Joppke, C., \& Morawska, E. (2014) Integrating immigrants in liberal nation-states: policies and practices. In Toward assimilation and citizenship: Immigrants in liberal nation-states (pp. 1-36). Palgrave Macmillan UK.

Joppke, C. (2014) European immigrant integration after multiculturalism. In Global and Asian Perspectives on International Migration (pp. 77-99). Springer International Publishing.

Kastoryano, R. (2005) (Ed.) Les code de la difference. Sciences Po Presses, Paris.

Keating A, Kerr D, Benton T, Mundy E and Lopes J (2010) Citizenship education in England 2001-2010. Report no. DFE-RR059 for the Department for Education, 21 September. UK.

Kern S (2014) The Islamization of Belgium and the Netherlands in 2013. Available at: http://www.gatestoneinstitute.org/4129/islamization-belgium-netherlands (accessed 4 November 2015)

Kymlicka W (2007) Multicultural Odysseys, Oxford University Press. 
Krippendorff K (2012) Content analysis: An introduction to its methodology. London: Sage.

Leeman Y and Pels T (2006). Citizenship education in the Dutch multi-ethnic context. European Education, 38(2), 64-75.

Mattei P (2012). The French republican school under pressure: falling standards and rising inequalities, French Politics, 10(1), 84-95

Mattei P and Aguilar A (2016). Secular Institutions, Islam and Education Policy: France and the US in Comparative Perspective. London: Springer.

Miller D (2006) Multiculturalism and the welfare state: theoretical reflections. In Banting K. and Kymlicka W. (eds.), Multiculturalism and the Welfare State, Oxford University Press, pp.177-201.

MCB (2015) Countering Extremism. Available at: http://www.mcb.org.uk/counteringextremism-mcb-gives-evidence-to-the-home-affairs-committee/ (accessed 31 May 2016)

Modood T and May S (2001) Multiculturalism and education in Britain: An internally contested debate. International Journal of Educational Research,35(3), 305317.

Modood, T (2013) Multiculturalism. $2^{\text {nd }}$ ed. Cambridge: Polity Press.

NCTV (2015) Radicalisering en rekrutering. [Radicalisation and recruitment]. Ministry of Safety and Justice. Available at: 
https://www.nctv.nl/onderwerpen/tb/watisterrorisme/radicalisering-rekrutering/ (accessed 22 May 2016)

OCW (2004, 23 April) Onderwijs, Integratie en Burgerschap. [Education, Integration and Citizenship]. PO/OO/2004/19279.

OCW (2013, 16 December) Parliamentary document 33750-VIII nr.80, Netherlands.

OCW (2015, 16 March) De rol van het onderwijs in de aanpak van radicalisering.

[The role of education in tackling radicalization]. Reference 741871, Netherlands.

Ofsted (2015) School inspection handbook. Reference no. 120101, August, Manchester: Crown.

OV-Raad (2015) Ondersteuning voor onderwijs bij aanpak radicalisering. [Support for education in addressing radicalization]. Available at: http://www.voraad.nl/themas/sociale-veiligheid/ondersteuning-voor-onderwijs-bij-aanpakradicalisering (accessed 4 November 2015)

Parekh, B. C. (2000). The future of multi-ethnic Britain: Report of the commission on the future of multi-ethnic Britain. The Runnymede Trust. London: Profile Books.

Parliament Communications (2009) Project CONTEST. Available at: http://www.publications.parliament.uk/pa/cm200809/cmselect/cmhaff/212/2120 5.htm (accessed 15 November 2015) 
Qurashi F (2016) Prevent gives people permission to hate Muslims - it has no place in schools. Available at:

http://www.theguardian.com/commentisfree/2016/apr/04/prevent-hate-muslims$\underline{\text { schools-terrorism-teachers-reject (accessed } 01 \text { June 2016) }}$

Race, R (2015) Multiculturalism and Education. $2^{\text {nd }}$ ed. Bloomsbury Academic.

Reich R (2002) Bridging Liberalism and Multiculturalism in American Education, Chicago: University of Chicago Press

RTL (2014a) Pro-ISIS-demonstranten aangehouden in Den Haag. Available at: http://www.rtlnieuws.nl/nieuws/binnenland/pro-isis-demonstrantenaangehouden-den-haag (accessed 13 November 2015)

RTL (2014b) 160 Nederlandse jihadisten naar Syrië of Irak vertrokken. [160 Dutch jihadists leave to Syria and Iraq]. Available at: http://www.rtlnieuws.nl/nieuws/binnenland/160-nederlandse-jihadisten-naarsyrie-irak-vertrokken (accessed 13 November 2015)

Schuh C, Burchardt M and Wohlrab-Sahr M (2012) Contested secularities: Religious minorities and secular progressivism in the Netherlands. Journal of Religion in Europe, 5(3), 349-383.

SLO (2006a) Een basis voor burgerschap. [A foundation for citizenship]. $\mathrm{BP} / 3528 / \mathrm{D} / 06-020$.

SLO (2006b) Kerndoelen. [Core values]. Available at: http://www.slo.nl/primair/kerndoelen/ (accessed 1 December 2015) 
SLO (2008) Omgaan met culturele diversiteit in het onderwijs. [Dealing with cultural diversity in education]. AN:7.4189.0089.

SLO (2009) Leerplanverkenning actief burgerschap. [Curriculum exploration for active citizenship] AN:7.5057.252.

SLO (2012) Advies: Verder met burgerschap in het onderwijs. [Advice: Continuing with citizenship in education]. Nr.20120192/1021.

SLO (2015) Op zoek naar gedeelde waarden. [In the search for shared values]. AN:7.7293.662.

Sniderman PM and Hagendoorn A (2007) When ways of life collide: Multiculturalism and its discontents in the Netherlands. Princeton University Press

Staatsblad (2005) Nr. 678, Law of 9 December 2005, Netherlands.

Staatsblad (2015) Nr. 238, Law of 4 June 2015, Netherlands

TK (2003-2004) Parliamentary document 29 203, nr.1, Netherlands

TK (2015) Debate of June 10, TK 94, (AO d.d. 03/06), Netherlands

Thomas, G. (2015) How to do your case study. London: Sage.

Tomlinson, S. (2001a) Education in a post-welfare society. Buckingham: Open University Press.

Tomlinson, S. (2001b) Multicultural education in the United Kingdom. In Banks, J. The Routledge International Companion to Multicultural Education. 
UK Government (July 2014) Consultation on promoting British values in school [Press Release]. Available at:

https://www.gov.uk/government/news/consultation-on-promoting-britishvalues-in-school

VJ, NCTV and SZW (2014) Actieprogramma Integrale Aanpak Jihadisme. [Integrated approach for the Jihadism action programme]. Available at:https://www.rijksoverheid.nl/documenten/rapporten/2014/08/30/actieprogram ma-integrale-aanpak-jihadisme (accessed 31 May 2016)

WWR (1989) Immigrant Policy. Scientific Council for Government Policy. The Hague, SDU

Word count: 8548 (Including References, Abstract and Keywords) 